Лобко М. М., канд. військ. наук, доцент ${ }^{1}$

$(0000-0002-3848-8772)$

Фучко А. Й. ${ }^{1}$

Копистира В. М. ${ }^{2}$

(0000-0002-3712-6809)

1_ Центр воєнно-стратегічних досліджень Національного університету оборони України імені Івана Черняховського, Київ;

2 - Національний університет оборони України імені Івана Черняховського, Київ

\title{
Інституційна модель системи оборони України
}

Резюме. У статті на основі аналізу вітчизняного законодавства розглядаються питання оборони, системи оборони, інституційної моделі системи оборони України з використанням системного підходу, її сутність, побудова. Розкриваються поняття “оборона України”, “система оборони”, “модель системи оборони України”. Сформовано структурно-описовий обрис “інституційної моделі системи оборони України”. Визначаються структура інституційної моделі системи оборони України: відношення, зв’язки та взаємодія між її елементами (компонентами) під час виконання покладених функцій і завдань оборони.

Ключові слова: оборона України; система оборони; інституційна модель системи оборони; складові моделі системи оборони.

Постановка проблеми. Вивчення досвіду відсічі збройної агресії Російської Федерації (РФ) проти України показало, що існуюча система оборони не повною мірою забезпечила виконання завдань оборони. Унаслідок збройної агресії Росією був анексований і тимчасово окупований Крим та частка території Донецької i Луганської областей. Отже, виникла нагальна потреба у суттєвому оновленні діючої системи оборони та формуванні іiі перспективної моделі, основаної на принципах і стандартах НАТО.

Аналіз останніх досліджень i публікацій. Питання, так чи інакше пов'язані iз системою оборони держави та іï моделлю, розглядали як вітчизняні, так й іноземні вчені, фахівці, експерти. Однак дослідження авторів здебільшого проводились стосовно певних складових цієї моделі. Так, у $[1,2]$ розглядались питання розбудови сучасної європейської моделі сектору безпеки i оборони України як важливого компонента моделі системи оборони, моделі управління постачанням сил сектору безпеки і оборони у єдиній системі матеріально-технічного забезпечення та ін. У $[3,4]$ досліджувалась модель оборонного планування за аналогією 3 НАТО та модель бойових дій сил і засобів протиповітряної оборони оперативного угруповання військ. Цілісно модель системи оборони нашої держави в наукових публікаціях не розглядалась.

У статті [5] автор визначає гіпотези щодо моделей оборони для ліпшого розуміння систем оборони, які існують у різних державах, та цілей кожної моделі й фактичних результатів іiі існування.
Слід зазначити, що в Україні триває оборонна реформа. Одним із наріжних завдань оборонної реформи $\epsilon$ формування перспективної моделі Збройних Сил України та інших складових сил оборони. Водночас, проводиться трансформація органів державної влади, інших державних органів, які пов'язані з обороною держави.

Мета статті - на основі аналізу вітчизняного законодавства, наукових публікацій розкрити сутність, склад i структуру моделі системи оборони України та надати структурно-описовий обрис інституційної моделі системи оборони України.

Викладення основного матеріалу. Оборона України базується на положенні Конституції України: “захист суверенітету i територіальної цілісності України, забезпечення іï економічної та інформаційної безпеки $є$ найважливішими функціями держави, справою всього Українського народу”.

Оборона Украӥни становить собою систему політичних, економічних, соціальних, воєнних, наукових, науковотехнічних, інформаційних, правових, організаційних, інших заходів держави щодо підготовки до збройного захисту та іï захист у разі збройної агресії або збройного конфлікту.

Однак сама “система заходів держави” $є$ суто переліком встановлених заходів, виконання яких забезпечать підготовку та оборону держави. Для реалізації встановленої “системи заходів держави” потрібно визначити відповідні суб'єкти державної 
влади, які мають бути наділеними відповідними повноваженнями, функціями i завданнями 3 їх виконання та задіяти необхідні сили і засоби держави. Сукупність визначених суб'єктів, діяльність яких спрямована на досягнення єдиної мети щодо забезпечення оборони та задіяні для цього сили i засоби держави становлять собою “систему оборони України”.

Отже, система оборони Украӥни - це організована державою сукупність органів державної влади, інших державних органів, органів місцевого самоврядування, усіх складових сектору безпеки і оборони України, єдиної системи цивільного захисту, національної економіки, інших складових, об'єднаних метою i завданнями, що здійснюють законодавчо встановлені повноваження, функції i завдання щодо забезпечення підготовки до оборони, оборони держави, захисту іï суверенітету, територіальної цілісності та інших національних інтересів у разі збройної агресії.

Для проведення наукових досліджень, пошуку шляхів подальшого реформування та розвитку системи оборони необхідно сформувати модель системи оборони України.

Довідка. Під моделлю слід розуміти ("модель", фр. modèle від лат. modulus "міра, аналог, взірець") аналог (як правило зменшений або уявний образ) об'єкта - оригінала (процесу, явища, системи), що підлягає науковому дослідженню з певною метою, прообраз, опис або зображення якогось об'єкта.

Модель це проєкт, інформаційне, натурноматеріальне чи описово-макетне уявлення об'єкта.

Існують різні види моделей i вони мають відповідати певним вимогам. Формуючи модель системи оборони слід зазначити, що вона має включати певну кількість елементів, які виконують визначені їм функції з оборони держави.

Модель системи оборони $є$ складною i охоплює всі інституції державного устрою встановленого законодавством держави, які мають повноваження, функції i завдання в частині підготовки, здійснення оборони та іï забезпечення (сприяння). Вона має об'єднувати воєнні, невоєнні, виробничі, інформаційні, ресурсні та інші можливості всіх іiі складових.

Сформована модель $є$ відповідним структурно-описовим обрисом, що утворює сукупний образ, загальний вигляд системи оборони. Вона надає уявлення про систему оборони, iï призначення, склад, структуру, розкриває характер та ті чи інші властивості. Сформована модель дає змогу досліджувати систему оборони, проводити певні експерименти, вносити необхідні зміни, уточнення, вдосконалювати та формувати іï перспективну модель.

Необхідно зазначити, що модель системи оборони України пройшла певний шлях становлення і розвитку та формувалась протягом тривалого часу незалежності нашої держави. Відтак, сформована модель системи оборони України є “інституційною”.

Інституційність моделі системи оборони полягає в тому, що основні іiі складові, їх повноваження, функції i завдання у сфері оборони встановлені положеннями вітчизняного законодавства, вона складалась і вдосконалювалась залежно від зміни світових геополітичних процесів, безпекового середовища, розвитку воєнно-політичної, воєнно-стратегічної обстановки довкола України, зростання загроз у воєнній сфері, збільшення обсягу завдань оборони та їх важливості.

Розглядаючи інституційну модель системи оборони України слід зазначити, що вона $\epsilon$ складною, ієрархічною, функціональною i, як зазначалось, включає значну кількість елементів, які за функціональною ознакою доцільно умовно розділити за відповідними компонентами (рис. 1).

Довідка. Поняття "компонент" слід розуміти як складову цілого, що становить собою сукупність певних елементів об'єднаних за функціональною ознакою.

Першою складовою моделі доцільно визначити ті іiі елементи, на які покладається виконання функцій управління щодо проведення комплексу заходів 3 підготовки держави до оборони та керівництво обороною під час відсічі збройної агресії. Такою складовою має бути керуючий компонент.

До керуючого компонента слід віднести: Президента України; Верховну Раду України; Раду національної безпеки і оборони України, Воєнний кабінет; вищий колегіальний стратегічний орган воєнного керівництва обороною держави в особливий період (Ставка Верховного Головнокомандувача), Кабінет Міністрів України; міністерства, центральні та інші органи виконавчої влади; місцеві державні адміністрації, ради оборони (Автономної Республіки Крим, областей, міст Києва та Севастополя), військово-цивільні (військові) адміністрації (у разі їх утворення) (ВЦА, ВА); органи військового управління; органи місцевого самоврядування на які 
покладено здійснення повноважень у сфері оборони.

Наступною складовою моделі необхідно визначити виконавчий компонент. До нього слід включити такі елементи: сектор безпеки i оборони України; національну економіку та інші підприємства, установи промисловості усіх форм власності, що беруть участь у забезпеченні оборони.

До наступної складової моделі необхідно віднести забезпечуючий компонент до якого необхідно віднести такі елементи: військового обов'язку та військової служби (ВО та ВС); мобілізаційної підготовки та мобілізації (МП та мобілізації); територіальної оборони України; єдиної державної системи цивільного захисту (ЄДС ЦЗ); єдиної транспортної системи України в особливий період; паливно-енергетичного комплексу в особливий період (ПЕК); єдиної системи державного матеріального резерву України (ССДМР); забезпечення інформаційної безпеки; національна система кібернетичної безпеки; підготовка населення i території держави до оборони.

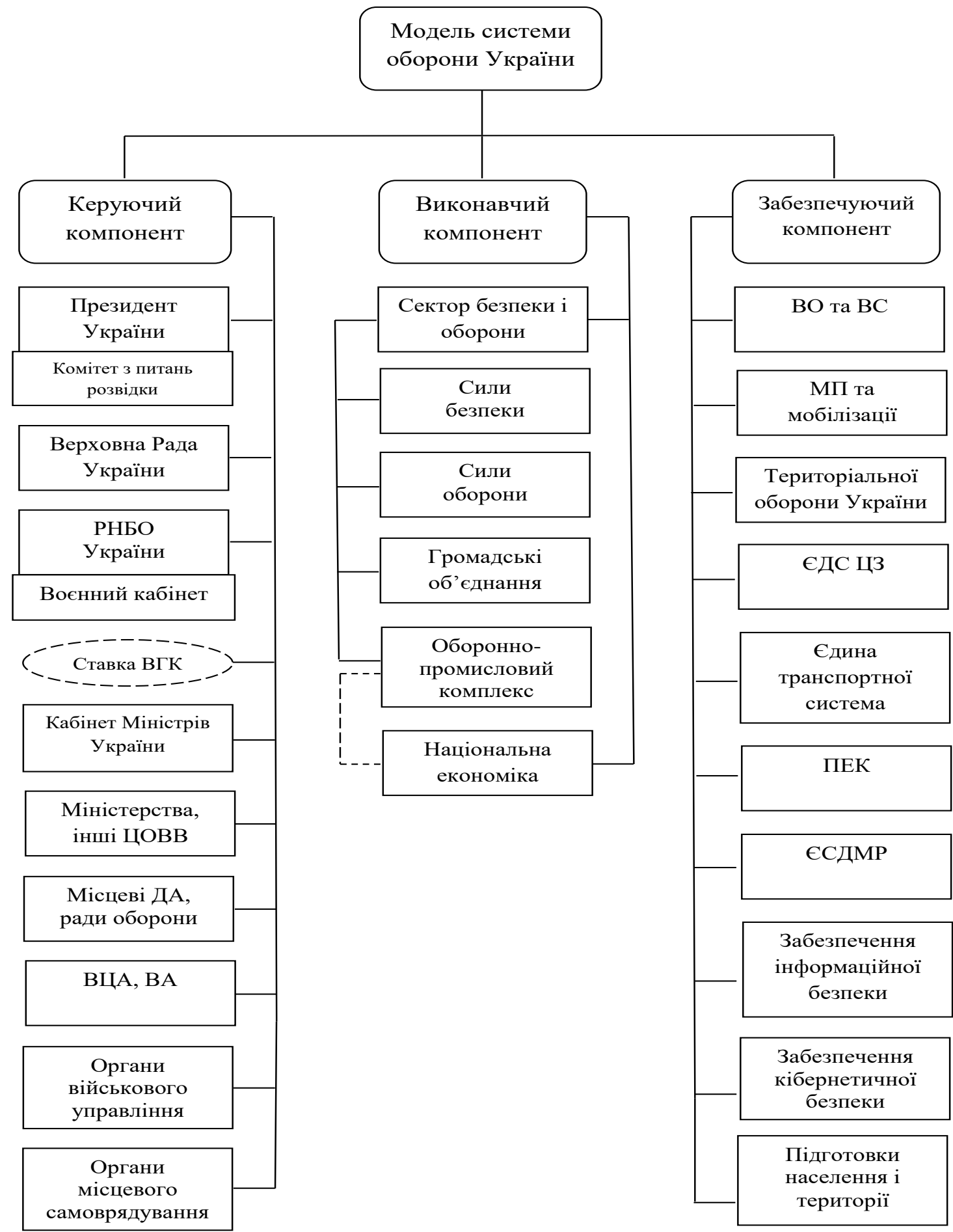

Рис. 1. Структура інституційної моделі системи оборони України 
Указані елементи безпосередньо не виконують завдання оборони, однак вони здійснюють різноманітні функції 3 iі підготовки та забезпечення (сприяння).

Зазначені складові системи оборони під час функціонування щодо виконання заходів і завдань оборони знаходяться у відповідних відносинах та взаємодіють між собою.

Наприклад, міністерства та інші органи виконавчої влади взаємодіючи організовують i забезпечують виконання законодавства у сфері оборони, сприяють Збройним Силам України, іншим військовим формуванням, розвідувальним і правоохоронним органам у виконанні ними завдань, належно забезпечують їх за напрямами діяльності, узгоджують з Генеральним штабом Збройних Сил України та забезпечують проведення заходів щодо розвитку системи зв'язку, шляхів, транспорту, інших об'єктів інфраструктури i території держави та підготовку своїх галузей до оборони, забезпечують їх територіальну оборону, планують, організовують і контролюють виконання заходів 3 мобілізаційної підготовки відповідних органів управління, установ, організацій і підприємств усіх форм власності та взаємодіють під час виконання інших повноважень, які належать до сфери їх управління.

Висновки. В Україні триває оборонна реформа одним із важливих завдань якої $\epsilon$ реформування та подальший розвиток основних складових системи оборони держави.

Існуюча система оборони має бути спроможною реалізувати визначений комплекс заходів держави щодо підготовки до оборони та ії захист у разі збройної агресії. Для цього вона має об'єднувати воєнні, невоєнні, виробничі, інформаційні, ресурсні та інші можливості всіх її складових.

Модель системи оборони держави слід розглядати як відображення сукупності елементів (компонентів) органів державної влади, інших державних органів, органів місцевого самоврядування, об'єднань громадян, національної економіки, сектору безпеки і оборони, цивільного захисту, інших складових держаного устрою, яким законодавчо визначені повноваження, функції i завдання 3 реалізації системи заходів держави щодо підготовки оборони та iї захисту у разі збройної агресії.

Сформовану модель системи оборони України потрібно розглядати як інституційну, що базується на положеннях вітчизняного законодавства i набула свого сучасного обрису протягом тривалого часу незалежності та розвитку нашої держави i iї обороноздатності.

Під час функціонування 3 виконання покладених завдань оборони складові системи оборони вступають у відповідні відносини та взаємодіють між собою.

\section{ПЕРЕЛІК ВИКОРИСТАНОЇ ЛІТЕРАТУРИ}

1. Турчинов В. Україна розбудовує сучасну європейську модель сектору безпеки і оборони. URL:

https://galinfo.com.ua/news/ukraina_rozbudovuie_su chasnu_ ievropeysku_model_sektoru_bezpeky_ i_oborony_307255.html (дата звернення: $02.02 .2021)$.

2. Сисоєв В. В. Модель управління постачанням сил сектору безпеки і оборони держави в єдиній системі матеріально-технічного забезпечення. Проблеми економіки = Theproblemsofeconomy. 2014. № 2. C. 144-153. URL: http://repository .kpi.kharkov.ua/handle/KhPI-Press/37703 (дата звернення: 02.02.2021).

3. Зміцнення обороноздатності: модель оборонного планування за аналогією 3 НАТО. Оборонний вісник. URL: http://defpol.org.ua/index.php/aleiaheroiv/705-zmitsnennya-oboronozdatnosti-modeloboronnoho-planuvannia-za-analohiieiu-z-nato (дата звернення: 06.02.2021).

4. Зварич С. С. Модель бойових дій сил та засобів протиповітряної оборони оперативного угруповання військ. Сучасні інформаиійні технології у сфері безпеки та оборони. 2012. № 3. C. 97-100. URL: http://nbuv.gov.ua/UJRN/ sitsbo 2012322 (дата звернення: 06.02.2021).

5. Глен Грант. Модель оборони: як зрозуміти стиль оборони країни. Виклики i ризики. Безпековий огляд ЦДАКРВ. URL: https://cacds.org.ua/?p=2239 (дата звернення: 06.02.2021).

Стаття надійшла до редакційної колегії 15.03.2021

\section{Institutional model of the Defense System of Ukraine}

\section{Annotation}

An analysis of the experience of repelling the armed aggression of the Russian Federation showed that the existing Defense System of Ukraine did not fully ensure the fulfillment of defense tasks that time. As a result during the armed aggression, Russian Federation annexed the Ukrainian Autonomous Republic of Crimea and occupied part of the territory of Donetsk and Luhansk regions. In order to 
increase the defense capabilities of our country, it was decided to upgrade Ukraine's Defense System and build a promising model based on modern principles and standards which are currently applied in NATO member countries.

The formed model is a corresponding structural and descriptive outline, which forms an aggregate image, a general view of the defense system. It provides an idea of the defense system, its purpose, composition and structure, reveals the nature and other properties. Created model provides an opportunity to study the Defense System for conducting a certain experiments, making changes and clarifications, with the purpose to making it better and use it for planning next long-term actions.

The institutional model of the Defense System is that its main components, their powers, functions and tasks in the field of defense are established by the provisions of domestic law. The Defense System was built and improved considering on the changes in the next spheres:

geopolitical;

security environment;

development of military-political, military-strategic situation around Ukraine; processes.

growing threats in the military sphere; increasing the volume of defense tasks and other important

According to the functional feature, the institutional model of the Defense System of Ukraine can be divided into appropriate components: management, executive and support.

Keywords: Defense System; defense of Ukraine; institutional model of the Defense System; components of the Defense System model. 